\author{
Asian Journal of Economic Modelling \\ $\operatorname{ISSN}(e): \quad 2312-3656$ \\ $\operatorname{ISSN}(p): \quad 2313-2884$ \\ DOI: $10.18488 /$ journal.8.2014.22.69.84 \\ Vol. 2, No. 2, 69-84 \\ (C) 2014. AESS Publications. All Rights Reserved. \\ URL: www.aessweb.com
}

\title{
CHALLENGES OF NEGOTIATING SECTORAL GOVERNANCE OF STREET VENDING SECTOR IN HARARE METROPOLITAN, ZIMBABWE
}

Tavonga Njaya

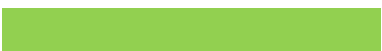

Keywords

Formalisation

Informality

Regulation

Sectoral governance

Street vendor

Street economy

Informal sector

Vending.

Faculty of Commerce and Law, Zimbabwe Open University, Zimbabwe.

\begin{abstract}
Informal businesses have decorated the streets of Harare and have become an increasingly visible and disruptive locus of conflict between the government's efforts to maintain public order on one hand and the citizens' efforts to generate income on the other. This study sought to investigate the problems hindering the establishment of a stable governance framework of street vending sector in Harare in Zimbabwe. The study used qualitative approach.Data were collected through in-depth personal interviews, direct observations and document reviews. Semi-structured questionnaires were administered to 145 street vendors in Harare. The study revealed that the inability to achieve stable governance of street vending may be rooted in problems at the national, metropolitan and local levels. First, policy contradictions caused by conflicting political incentives at different levels of the state have made establishment of sectoral governance rather elusive. Second, at the metropolitan level, neoliberal by-laws and regulations continued to exclude street vendors from participating in the economic activities of the country. These by-laws have failed to adapt to the changing circumstances. Third, street vendors lacked formal association(s) that can coordinate strategies across different groups to achieve sectoral governance. The study provided an insight into an emerging research area that is characterised by a proliferation of a variety of types of street vendors in Harare. The study showed that while vending associations had been unsuccessful in their efforts to achieve sectoral governance, the new interest regime could offer novel strategies of action to achieve this goal.
\end{abstract}

Contribution/ Originality: This study is one of very few studies which have investigated challenges of formalising street vending in Zimbabwe. Street vendors have neither legal right to work nor voice to influence urban planning. 


\section{BACKGROUND OF THE STUDY}

Street vending as an occupation has existed for hundreds of years (Bromley, 2000) and has become an integral component of most urban economies. In the literature on street vending, street vendors are broadly classified as vendors who sell goods or services in public spaces including sidewalks, alleyways, train stations, buses and public parks. "Street vendor" may refer to vendors with fixed stalls, such as kiosks; vendors who operate from semi-fixed stalls, like folding tables, crates, collapsible stands, or wheeled pushcarts that are removed from the streets and stored overnight; vendors who sell from fixed locations without a stall structure, displaying merchandise on cloth or plastic sheets; or mobile vendors who walk or bicycle through the streets as they sell (Roever, 2010). In this study, the term street vendor includes stationary and mobile vendors. Street vendors may be stationary in the sense that they occupy space on the pavements or other public/private spaces or they may be mobile in the sense that they move from place to place by carrying their wares on push carts or in baskets on their heads (Bhowmik, 2005). In this study, the terms "street vendor", "street trader", "hawker" and "peddler" have the same meaning and they are often interchanged.

Street vendors are part of a growing informal economy (Flodman-Becker, 2004) who invariably escape compliance with state regulations of their business enterprises. In almost all Asian countries, street vendors have no legal status to conduct their business and they are constantly harassed by the authorities (Bhowmik, 2005). The reasons for the rapid growth of the informal economy in developing countries include limited absorption of surplus labour by agriculture and formal economy; barriers to entry into the formal economy such as excessive costs and government regulations (Hernando, 2000); weak capability of institutions to provide education, training and infrastructure; redundancies during structural programmes; demand for low cost goods and services; globalisation of world economy that tends to privilege capital and disadvantage labour especially lower skilled workers who cannot easily migrate (Roever, 2010);lack of government commitment to support the informal sector; rural-urban migration caused by poverty and the impact of HIV and AIDS and the rising number of women entering the labour markets. In Ghana, Hart (1973) observed that price inflation, inadequate wages and an increasing surplus to the requirements of the urban labour market led to a high degree of informality in the income generating activities of the sub-proletariat. Hart (1973) argued that government planning and the effective application of economic theory in this sphere had been impeded by a wholesale transfer of western categories to the economic and social structures of African cities. The practice of street vending generates enormous controversy (Bromley, 2000) and the core debates revolve around the idea of formalisation. However, there are challenges to integrating informal businesses into the mainstream economy though the benefits of formalisation are compelling. In Lima, Peru, the historical pattern of informal street vending was transformed through formalization (Bettcher et al., 2009). This involved giving property rights to street vendors, reducing barriers to market entry, introducing cost-effective regulations and democratic policy process. Bettcher et al. (2009) reported that between 1991 and 1994, about 382100 street businesses belonging mainly to the poor were formalised and contributed US $\$ 692.5$ million in licence fees and created 550 oo jobs. Roever (2005) observed that intractable conflicts between 
vendors and government of Peru arose not over the issue of formalisation per se, but rather over the specific terms of formalisation. She noted that negotiations over the terms of formality were conditioned by changing political circumstances at the national, metropolitan and local levels.

As a result different configurations of vendor allies and opponents created strong incentives for hindering enforcement of formalisation measures at the local level (Roever, 2005). In India, street vending organisations campaigned successfully for inclusive practices, national policy and law on street commerce (Chen, 2012). In some countries for example, South Africa, street vending organisations have become very influential over city planning in Durban.

In the case of Harare, negotiations over formality are a source of protracted conflict between street vendors and the City Council who have been unable to jointly construct a stable regime of sectoral governance. But what are the sources of conflict between the City Council and street traders? How can the City Council and government in general disregard a sector of the economy where the majority of the population is supporting itself? Can the perceived problems of street vending be resolved through formalisation? Are there any strategies towards formalisation of street vending in Zimbabwe? What are the problems hindering the formalisation of street vending sector? These were the overarching questions addressed by the study.

The paper is organised as follows. The background of the study and review of related literature have been discussed in this introductory section. Research objectives and corresponding research questions are outlined in section two. The research methodology of the study is explained in section three. Section four presents findings from the study. The conclusion and recommendations are discussed in the last section.

\section{STUDY OBJECTIVES}

The study sought to investigate the problems hindering the establishment of a stable governance framework of street vending sector in Harare in Zimbabwe. The specific objectives of the study were:

- To identify emerging street vending activities or patterns in Harare.

- To identify factors promoting street vending in Harare.

- To evaluate factors hindering the establishment of stable governance framework of street vending sector in Harare.

- To make suggestions for policy recommendations to enable planning and development of sustainable strategies of formalising street vending in Harare.

\subsection{Research Questions}

- What are the emerging street vending activities or patterns in Harare?

- What factors are promoting street vending in Harare?

- What are the factors hindering the establishment of stable governance framework of street vending sector in Harare?

- What are the policy recommendations that can enable planning and development of sustainable strategies of formalising street vending in Harare? 


\section{STUDY METHODOLOGY}

The study used mixed method research (Bryman, 2006) where the qualitative approach predominated over the quantitative approach. The population of the study included all street vendors in Harare. Harare was purposively selected for the study because the City experienced the highest proliferation of street vendors in Zimbabwe. During the 2012 census, Harare recorded the highest population of 16.2 percent (ZIMSTAT Zimbabwe National Statistics Agency), 2012). Data collection techniques included interviews, focus groups, observations and document reviews. A short questionnaire with most open-ended questions was prepared and administered to 145 street vendors. Street vendors were divided into subpopulations called strata according to location of vending sites. The questionnaire was distributed as follows: 60 street vendors in the six high density suburbs of Budiriro, Highfield, Glen Norah, Glen View, Mufakose and Warren Park; 15 vendors in medium-density suburbs of Zimre Park and Southerton; ten vendors in the low density suburbs of Avondale and Highlands and 60 vendors in the city centre. The rationale was that street traders are not a homogenous group and hence a more representative sample could be obtained through the stratified sampling technique. In addition, stratified sampling allowed for intentional oversampling which permitted greater statistical precision (Boslaugh, 2007). In-depth interviews were held with two councillors; two officials from Harare City, one in the Department of Health Services and one in the Department of Housing and Community Services in order to enrich the study.

\section{PRESENTATION AND DISCUSSION OF RESEARCH FINDINGS}

The questionnaire was structured to find out the demographic characteristics of street vendors; forms or modalities of street vending; employment status of street traders; driving forces behind street commerce; problems caused by street vending; risks faced by street vendors and factors hindering formalisation of street vending.

\subsection{Demographic Characteristics of Street Traders}

Table 4.1 shows the demographic characteristics of street vendors in Harare. A majority of the street vendors were from poor backgrounds. Women were predominant in street vending representing 53.1 percent. The number of males involved in street commerce was 48.9 percent. A majority of the street vendors (75.2 percent) were in the economically active age groups of 21-30 and 31-40 years. This group's participation in street vending sector reflected the high unemployment levels in Zimbabwe. The informal sector has become the only source of income for the unemployed because of relatively low capital requirements. Peak prevalence in education was Ordinary Level with 55.2 percent of all street vendors in the sample. Traditionally street vending was associated with women particularly house wives but had become open to both sexes in all age groups. This demonstrated that an increasing number of Zimbabweans depended on the informal sector for their livelihoods and survival. In the study, 88.3 percent of the vendors indicated that street enterprise was their sole source of income.

An interesting observation in Table 4.1 is an increasing number of university graduates $(8.3$ percent) who were joining street commerce. Educated or graduate unemployment should be a 
throbbing issue to the government. Graduate participation in street trade represents gross underemployment of the country's human capital. Research has shown that unemployment and/or underemployment of graduates are devastating phenomena in the lives of graduates and a high incidence of either is an indicator of institutional ineffectiveness and inefficiency (Bruwer, 1998).

The graduate vendors interviewed regarded street vending as refuge occupation where they could earn subsistence income. Probably further research would be required in this area. Meanwhile research in Lusaka, Zambia and Kampala, Uganda did not find street vendors with tertiary education (Ndhlovu, 2011). In these countries, the majority of street vendors had reached high school.

Table-4.1. Demographic characteristics of street vendors in Harare

\begin{tabular}{l|l}
\hline Parameter & Percentage (Frequency, n=145) \\
\hline Age (years) & \\
\hline Below 20 & 4.1 \\
$21-30$ & 33.1 \\
$31-40$ & 42.1 \\
$41-50$ & 13.3 \\
$51-60$ & 6.2 \\
Over 60 & 1.2 \\
\hline Sex & \\
\hline Male & 46.9 \\
Female & 53.1 \\
\hline Marital Status & \\
\hline Single & 24.8 \\
Married & 57.2 \\
Divorced & 6.3 \\
Widowed & 11.7 \\
\hline Educational Qualification & \\
\hline Ordinary Level & 55.2 \\
Advanced Level & 14.5 \\
Diploma & 10.3 \\
Degree & 8.3 \\
Other & 11.7 \\
\hline Other refers to those without secondary education. & \\
Source: Author, 2014. &
\end{tabular}

\subsection{Forms of Street Traders}

Street vending varies in terms of scale, timing, location, remuneration, workforce and type of goods sold and services provided (Bromley, 2000). Harare experienced an enormous growth in street vending over the last decade with vendors selling everything from fresh food and medical drugs to mobile phones and mobile recharge cards, electrical gadgets (TV sets, stereos), cars, bricks and sand. Meanwhile other vendors provided services on the streets and predominant among them included haircut, hair plaiting, manicure and pedicure, car wash, bicycle repair, cell phone unlocking and installation of internet and whatsApp on cell phones and mending. Street vendors were observed in most public and private places including industrial and construction sites, hospitals, schools, sporting stadia, bus termini, church buildings, shopping and commercial centres, pavements, sidewalks alleyways, open spaces and along virtually every street of Harare's 
suburbs as well as the central business district. The major categories of street vendors observed included mobile, stationary, fixed and itinerant vendors. The facilities used included kiosks, open spaces, wooden or canvas or polythene stalls, hawker's kiosks, push carts, cycles, collapsible stands, semi-fixed stalls such as folding tables, crates, trucks, other vehicles (sedan, suv or hatchback), vans and vans with specific food service equipment. The selling of merchandise from a car boots was becoming a common phenomenon in Harare especially during weekends. Organised car boot sales were usually conducted as fundraising activities by schools and church organisations where individuals came together to sell old as well as new goods. In the case of street food vending, Njaya (2014) observed that the equipment used included baskets, plastic boxes, firewood braziers, gas stoves, braai stands, cooler boxes, plastic buckets and refrigerators while cooking utensils observed included pots and pans (usually black which are suitable for use on fire, spoons, (wooden and metal), plates (metal and plastic), knives, cups (metal and plastic), dishes or bowls (metal and plastic).

\subsection{Employment Status of Street Vendors}

The researcher observed varied employment context of street traders that included:

- independent and self-employed entrepreneurs either with or without employees

- street vendors who work as contributing family members

- vendors who work as employees of formal or informal enterprises

- vendors who sell goods on commission for formal or informal enterprises

- part-time vendors who hold down formal jobs

- seasonal vendors of specialty goods

- permanent vendors who regard vending as their primary occupation

- opportunist vendors who only vend when an opportunity presents itself

\subsection{Factors Promoting Street Vending in Harare}

The driving forces behind street vending as with the informal economy as a whole are diverse. The following were cited by street traders as the main driving forces behind street trade in Harare:

- quick and easy avenue to earn subsistence income

- $\quad$ social system for the under-privileged urban dwellers

- failure to find jobs in the formal economy

- response to known demand from customers who prefer open-air environment of shopping

- low barriers to entry which makes street vending a refuge occupation

- easy accessibility and low initial capital requirements

- more flexible and/or attractive employment option than wage wok

- no overhead costs of rentals, rates and sometimes licensing fees

- flexibility of working hours allows women (especially housewives) to fulfill their household care chores

- redundancies or retrenchments caused mainly by economic crisis 
- $\quad$ retirement

\subsection{Problems Caused by Street Vendors}

According to Njaya (2014), the following were cited by the Harare City Council as the main problems caused by street commerce:

- overcrowding on City pavements as vendors display their merchandise in front of licensed shops and offices

- obstruction of fellow citizens doing their business

- unsafe foods are sold on the streets

- vendors' business refuse (garbage) cause unsightly urban vista

- hazardous environment caused by the absence of water and sanitation at some vending sites

- street vending obstructs the maintenance of law and order

- non-compliance of street businesses with municipal by-laws and regulations

- illegal and hazardous products

- public utilities (water, electricity and waste disposal) are overstretched

- traffic congestion due to spill-over business of street vendors

- $\quad$ some street vendors work in cohorts with criminals

- noise as street vendors often advertise by loud cries or chants so as to attract the attention of customers

The City Council responded to the above problems by evicting street vendors en-masse. Njaya (2014) observed that despite these violent evictions and confiscations of merchandise, street traders continued to occupy new locations and to operate outside the bounds of the law. However, remaining on the streets involved high costs of insecurity and regular evictions though the benefits of street selling were more compelling to the street entrepreneurs. The following section looks at issues of formality and regulation of street commerce in Harare.

\subsection{Formality and Regulation of Street Vending in Harare}

Although it is exceedingly difficult to produce accurate estimates of the number of street vendors in Harare, their number had significantly increased over the last decade. This however was not unique to Zimbabwe as the number of street traders had been increasing worldwide (Carr and Chen, 2002). Some of the factors behind the rise in the number of street traders included rural-urban migration of low skilled workers towards cities, redundancies caused by the worsening economic crisis and lack of employment opportunities in the formal sector. Bromley (2000) observes that lack of data on street vendors sometimes makes it difficult to ascertain if their number is growing faster than would be accounted for naturally by urban population growth. In Harare, the rising numbers of street vendors raised concerns about congestion, environment, cleanliness and hygiene which led urban services to be overstretched resulting in inadequate supplies of potable water and sewage disposal. Street vending is closely connected with the availability of urban public space, pavements, roads, parks and beaches and many of the 
difficulties associated to the activity including the negative way it is perceived by the wider society are linked to the ways in which such spaces are managed by the authorities (Bromley, 2000).

Street vending is illegal in Harare. Vending is only allowed in designated areas for example in flea markets. In a flea market, vendors rent space to sell merchandise (both used and new) usually at "low" prices. A flea market may be indoors (for example, Mupedzanhamo Flea Market in Mbare) or out-doors as in a parking lot (for example, Harare Charge Office Flea Market in the central business district) or open space (for example, Avondale Shopping Centre Flea Market). Mupedzanhamo Flea Market is probably the most vibrant and densely populated open market in Zimbabwe. When flea markets were introduced in the early 1990s, trading was restricted to weekends but some of them now operate every day. Two types of vendors were found in the flea markets including traders who set up a small stall to sell various new and used goods and dealers of used goods. The dealers of used goods were in two groups: dealers who actually owned shops who frequently prowled flea markets looking for merchandise to sell at a higher price and dealers who had stalls in flea markets outside Harare. The City Council designated more open spaces as flea markets during the weekends. I was informed that there was partisan allocation of flea market sites as well as selection of the vendors where certain areas were known to be for either ZANU$\mathrm{PF}$ (the ruling party) or MDC-T (opposition party with a higher number of councillors and members of parliament in Harare). During the field work, I observed that some flea markets had food vendors who sold snacks and drinks as well as main meals like rice and sadza served with beef, chicken and fish. Besides the registered flea markets, there were illegal flea markets in some public spaces. Because these vending sites did not have hanging facilities of merchandise, they were often referred to as "kotamai" boutiques.

On the other hand, City by-laws did not allow vending of cooked food. Instead, the City issued hawker's licenses which included a restriction on the type of food sold (vegetables) and the location where they could be sold. Vending of cooked foods was governed by the Public Health Act, Chapter 15.09 and the Food and Food Standard Act, Chapter 15.04. As observed by Njaya (2014), the Public Health Act and the Food and Foods Standards Act have origins in colonialism and were designed to protect established businesses (mostly white and Asian) while subjecting small businesses (mostly owned by blacks) to harassment for failure to meet prescribed standards. Most food vending operations took place at undesignated sites except for Mereki in Warren Park D (Njaya, 2014).

Harare (Hawkers) By-laws 2013 state that "...no person shall engage another to carry the business of hawking unless he or she is in possession of a valid hawker's employers' license." The license costs US\$120 per annum and must specify the number of hawkers that the holder may employ or retain as an agent. The regulations stipulate that no hawker shall remain stationary while conducting his or her business for more than 15 minutes. The by-laws also state that the Council may refuse to issue or renew a hawker's license if in its opinion, “...the issue of renewal would adversely affect any existing trade or businesses carried out in the area.” 


\subsection{Risks Faced by Street Vendors}

The following were listed by street traders as the major risks they faced in their business;

- irregular and fluctuating incomes

- long working hours

- constant raids and/or evictions

- confiscation of merchandise by both the national and municipal police

- competition from new entrants which eroded profits

- erratic supply of raw materials

- vendors who sell perishables (mostly women) suffer constant losses

- lack of business management skills (especially vending skills)

- lack of institutional credit facilities

- harassment and exploitation by national police and municipal authorities

- lack of social protection

- constant fatigue caused by spending long hours in inclement weather (sun, rain, heat and cold)

- lack of public utilities (roads, electricity, toilets, potable water and waste disposal)

- dangers of accidents especially for vendors at busy road junctions

- poor health

- poor safety conditions

- exposure to high concentration of air pollutants

- lack of organisational strength and voice

- lack of dignity

- lack of right to work

- demand of bribes (protection fees) by municipal and national police for vendors to continue on the street

- lift and haul heavy loads of merchandise to and from vending sites everyday

Generally speaking, street vendors' legal status could act as a buffer between their employment conditions and the range of employment risks outlined above. A vendor with a fixed structure in a designated market, for example flea markets, may be more likely to hold a license and in turn would be less exposed to some of the risks identified. Likewise, a street vendor who works as an employee selling particular products such as newspapers or ice cream may be better protected by the law and therefore less vulnerable. This demonstrates that obtaining legal status must therefore be a key demand of street traders in Zimbabwe. Giving legal recognition to street vendors has tremendous benefits to the vendors themselves and government. For example, under the Warwick Junction Project, the Durban City, South Africa, constructed infrastructure that provided street vendors with basic shelter and amenities. Each vendor was allocated a kiosk which gave them trading space, more security, income and income potential. However, issues of legality and formalisation would revolve around three basic issues, namely, registration (licensing) and authorisation, taxation and policy participation. But why has formalisation of street commerce been elusive in Harare and Zimbabwe at large? 


\subsection{Factors Hindering the Establishment of Stable Governance Framework of Street Vending}

The policy environment for street traders is a function of both the legal context and the political environment (Women in Informal Employment Globalisation and Organising, 2012). In terms of the legal context, Zimbabwe has constitutional provisions related to the individual rights to work and to private property and the collective rights to public space and economic association that also cover street vendors. However, aside from these constitutional provisions, Zimbabwe did not have a national policy on street commerce. This was in spite of the fact that a majority of the population derived its livelihoods from the informal sector which included street trade. The recognition and appreciation of the role of informal workers in general and street vendors in particular is important particularly for Zimbabwe where the formal jobs are diminishing. In the literature countries that have national policies on street vending include, United States of America, United Kingdom and France, India (Sinha and Roever, 2011); Peru (Bettcher et al., 2009); Barbados and Bahamas in Caribbean Islands (Dardano, 2003). In India, a national policy on street vending was adopted in 2004 reflecting a change from prohibition to regulation (Sinha and Roever, 2011). And in order to give legislative support to the national policy on street vending, the Federal Government of India passed the Protection of Livelihood and Regulation of Street Vending Bill which protects street vendors from harassment and eviction. The Bill was an outcome of organised advocacy of street vendor organisations and federations across India under the National Association of Street Vendors (Sinha and Roever, 2011).In Dar es Salaam, Tanzania, street traders were issued licenses and allowed to operate in the early 1990 s (Carr and Chen, 2002).

At the local level, the study noted that City by-laws and regulations governed street commerce. These by-laws and regulations emanated from urban planning processes that invariably excluded street traders. For example, most vending sites were found to be generally filthy, dusty and smoky. A majority of these vending sites were deemed illegal by the City Council. The City by-laws should not seek to exclude street vendors but should seek to establish regulatory mechanisms of street vending through licensing. Where food vending took place, inconvenient and unhygienic eating places were the major infrastructural problems observed. A small group of vendors had facilities for the storage of refuse in plastic bags or bins. However, sometimes food scraps were indiscriminately and/or accidentally deposited by consumers at the service site. The failure to remove this litter created unsightly conditions and attracted rodents and insects.Njaya (2014) observed that the cooking areas were often situated near rubbish dumps, skip bins or public toilets exposing both the vendors and consumers to food contamination. More than 85 percent of the public toilets (most of them within the proximity of the vending sites) were not in working order. The researcher was informed by the vendors that sometimes the skip bins were not emptied on a regular basis.

But why would the Harare City ignore a sector where a majority of its citizens obtained its livelihoods? Generally, urban space tends to be a highly political issue involving many interests (Kusakabe, 2006). Neoliberal policies and the generally accepted partiality towards modern infrastructure results in a total rejection of traditional and "primitive" livelihoods activities conducted on pavements, sidewalk s and licensed shops' premises. This has often resulted in 
established retail outlets, fearing competition from street traders lobbying the City Council to evict the latter. Street vendors are regarded as disruptive competitors. During the fieldwork, I observed that discrimination against these disruptive competitors did not only come in overt regulatory prohibitions but also came in more subtle forms such as selective enforcement of existing by-laws and regulations. For example, in the High density Suburbs of Glen Norah and Glen View sometimes police raids only targeted street vendors selling grocery items such as sugar, salt, cooking oil, margarine and mealie-meal while leaving out vendors selling different merchandise. Sometimes local business associations used their political connections and associations to block disruptive competition from street traders. However, using government power to place burdensome restrictions on street traders in order to protect licensed shops from competition was not a valid use of state policing power and could only work in the short run. Instead, the City Council should encourage the entrepreneurship of street vendors and not stifle it through vindictive protectionist by-laws. On the other hand, the licensed shops should adapt to the new circumstances and compete on the basis of quality, service and price.

Njaya (2014) observed that the major problem seemed to be the City's master plan (designed during the colonial period) which did not allocate space to vendors as town planners blindly replicated the western concept of marketing which ignored the Zimbabwean traditions. Hart (1973) concurred and argued that government planning and the effective application of economic theory in the informal economy had been impeded by a wholesale transfer of western categories to the economic and social structures of African cities. According to Njaya (2014) the modern development approach is oriented towards shopping malls which are not built on the concept of a public that cannot afford to live expensive lifestyles. The City by-laws should be adapted to the changing circumstances to accommodate street economic activities but at the same time retaining the ability to regulate the operations of street trade. In order to integrate street vendors meaningfully into urban planning, it is essential to see urban spaces as multi-functional and multilayered (Kusakabe, 2006) instead of linking urban space to one function. Currently, a majority of the street vendors are free riders of urban space and public utilities (water, electricity, waste disposal and toilets).

Another observation was that the political environment seemed to influence the policy mix towards street business in Harare. In an effort to attract foreign investment through campaigns for "world class city" status has resulted in policies that threaten the livelihoods of street vendors. The City Council's primary objective is to beautify the city without reference to street vendors. Meanwhile, the ability of street vendors to influence political outcomes is curtailed by lack of voice in the city planning and policy making processes as well as their exclusion from policy circles.

Another interesting observation was that policies towards street commerce were contingent and fluid and often flowing together with political outcomes and bureaucratic currency of the day. Political parties seem to render lip service to street vending without doing anything concrete to improve their security. However, during election times political parties resuscitate alliances with vendors in anticipation of their votes. Urban areas were controlled by the Movement for Democratic Change (MDC) but the Minister of Local Government and Urban Development who 
had overall charge of local governance in Zimbabwe was from ZANU-PF. This often caused discord on how street vendors should be treated depending on the political stakes attached to the decision to be made. For example, in 2005 the government demolished informal structures under Operation Murambatsvina in order to clean the City. However, the opposition attacked the government for destroying livelihoods of the urban poor. During interviews with vendors in Mbare Musika and Mupedzanhamo, I was informed that the ruling party often mobilised them for political purposes. However, this practice was not unique to Zimbabwe. Bhowmik (2005) observed that in most countries where the number of street vendors was large, the ruling parties used the vendors for their political gains though the street traders themselves did not get any tangible benefits from the alliance.

According to Bromley (2000), street vending is very difficult to regulate because of its mobile nature as street vendors may move depending on events in a city, the weather, customers' location and the time of day. He noted that solutions that involve the creation of off-street markets could not work because customers did not necessarily follow the vendors who are then rapidly replaced by new vendors in their previous location. As a result a single market governance framework inclusive of all street traders therefore becomes impractical given the differences in profile and resources of street vendors.

Another observation that prohibited the establishment of sectoral governance of street commerce was that street vendors lacked formal association(s) that could coordinate strategies across different groups to gain recognition by the state. Except for local associations which were characterised by rotating savings clubs, street vendors did not have a common forum where they could engage the City Council. On the other hand, established shops were organised and had associations whose mandate was to work the political and regulatory system to their advantage. Furthermore, the established shops paid rent, property licenses, rates and fees which filled political coffers unlike street vendors who were free riders. In addition, established shops would always spin a narrative about how disruptive competition would force them to lay-off workers. This tended to overshadow the net gains in employment from street vending and net consumer surplus generated.

According to the street vendors, the City by-laws and regulations were rigid and insensitive to their plight. The street vendors recommended that the City by-laws should be adapted to the changing circumstances to accommodate street economic activities but at the same time retaining the ability to regulate the operations of street trade. However, as already observed by Njaya (2014), the modern development approach is oriented towards shopping malls which are not built on the concept of a public that cannot afford to live expensive lifestyles. For example, most car washers interviewed said that they could not formalise their businesses as they did not have the resources to put up the required structures and pay the rentals to council.

\section{CONCLUSION AND RECOMMENDATIONS}

The business of street vending needs to be addressed carefully in order to derive maximum benefits for the entire economy. Generally, there is need to integrate the street economy into the mainstream economy in a way that would ensure sustainability of the former and long-term 
economic growth and sustainable development of the country. However integrating the informal economy into the mainstream economy is a great challenge to most governments in developing countries. A sustainable strategy to reform the business environment would be to allow the street entrepreneurs to find their own way (out of informality) if given access to the formal sector. This is what De Soto referred to as "building a bridge from informality to formality". The study revealed that the inability to achieve stable governance framework of street vending may be rooted in problems at the national, metropolitan and local levels. First, policy contradictions caused by conflicting political incentives at different levels of the state have made establishment of sectoral governance rather elusive. At government level, the attitude towards street traders has been ambivalent, vacillating between tacit support (where vendors' votes mattered) and open revulsion. Second, at the metropolitan level, neoliberal by-laws and regulations continued to exclude street vendors from participating in the economic activities of the country. These bylaws have failed to adapt to the changing circumstances. Third, street vendors lack formal association(s) that can coordinate strategies across different groups to gain recognition by the state and hence achieve sectoral governance. The study provides an insight into an emerging research area that is characterised by a proliferation of a variety of types of street vendors in Harare. The rising numbers of street vendors have raised concerns about congestion, cleanliness and hygiene which have led urban services to be stretched beyond their limits resulting in inadequate supplies of potable water and sewage disposal. The study provided an insight into an emerging research area of street commerce by analysing the economic, political and social conditions that define informality.

The following recommendations emanated from the study. The recommendations are in four categories; recommendations specific to the Government of Zimbabwe, Harare City Council, Nongovernmental organisations and street vendors.

\subsection{Government of Zimbabwe}

- Provide legal recognition of street vendors' rights. As a first step towards legal recognition of street traders' rights, there is need to analyse legal obstacles and extra-legal practices that hinder smooth formalisation of informal traders.

- Prepare and implement a national policy on street vending to ensure sustainable improvement of the sector.

- Licensing, registration and codes of conduct/practice at the national level need to be established as essential components of sound regulations for street vending in Zimbabwe.

- Increase street traders' visibility in official statistics.

\subsection{Harare City Council}

- Register and license all street vendors.

- Conduct a survey that would focus on compiling data to identify and profile the nature of street traders (mobile, semi-mobile, static and footpath vendors) and establish the number of people who depend on street vending for their livelihoods, people who buy street commodities and suppliers of raw materials or finished products to street vendors. 
- Develop code of practice, registration and licensing of street vendors at the local level.

- Engage street entrepreneurs on how they can move from informality to formality.

- Lower costs of access to formal markets.

- Allocate public spaces to street vendors.

- Rehabilitate toilets and provide potable water as well as sanitary facilities at vending sites already in use.

- Construct decent shelters which could be rented out to street vendors.

\subsection{Non-Governmental Organisations}

- Assist in establishing and strengthening street vending organisations.

- Start regular consultations to coordinate advocacy programmes with a view to recognition and formalisation of street vending.

- Assist to strengthen the voice of street traders in policy making and city planning processes.

- Mobilise and consult informal traders on issues of property rights and dealings with government and City authorities.

- Design and conduct on the job training seminars for street vendors on issues of marketing, credit, business development and food handling and hygiene where food vending is involved.

\subsection{Street Vendors}

- Establish street vending organisations which should develop code of practice for street businesses. The street vending organisations would become a forum for interaction with the City of Harare and Government.

- Establish associations that can pool resources together for bigger investments in say real estate which can then be developed and rented to members and other informal traders.

\section{REFERENCES}

Bettcher, K.E., M. Friedl and G. Marini, 2009. From the streets to markets: Formalisation of street vendors in metropolitan lima, No.0901 May 21, 2009. Washington D.C.: Centre for International Private $\begin{array}{lll}\text { Enterprise. Available from } & \text { An }\end{array}$ www.cipe.org/publications/papers/pdf/Lima\%20Markets\%20Case\%20Study.pdf [Accessed on 4 April, 2014].

Bhowmik, S., 2005. Street vendors in Asia: A review. Economic and Political Weekly, May28-4 June 2005,

$$
\text { XL(22-23): 2256-2264. Available from }
$$
http://wiego.org/sites/wiego.org/files/publications/files/Bhowmik-Street-Vendors-Asia.pdf

[Accessed 4 April 2014].

Boslaugh, S., 2007. Secondary data sources of public health: Practical guides to biostatistics and epidemiology. 1st Edn., New York: Cambridge University Press. 
Bromley, R., 2000. Street vending and public policy. A global review. International Journal of Sociology and Social Policy, 20(1-2): 1-19. Available from http://wiego.org/publications/street-vending-andpublic-policy-global-reviewinternational-journal-sociology-and-socia [Accessed 4 April, 2014 ].

Bruwer, J., 1998. First destination graduate employment as key performance indicator: Outcomes assessment perspectives. Cape Town, South Africa: Unit of Institutional Research. Available from http://www.aair.org.au/jir/1998papers/bruwer.pdf [10 March 2014].

Bryman, A.E., 2006. Integrating quantitative and qualitative research: How is it done? Journal of Mixed Methods Research, 6(1): 97-113. 9vailable from http://www.socsci.uci.edu/ssarc/sshonors/webdocs/Integratingqualandquant.pdf [Accessed 16 October 2012].

Carr, M. and M.A. Chen, 2002. Globalisation and the informal economy: How global trade and investment impact on the working poor. Geneva: International Labour Organisation. Available from http://www.ilo.org/wcmsp5/groups/public/--ed_emp/documents/publication/wcms_122053.pdf [4 April 2014].

Chen, M.A., 2012. The informal economy: Definitions, theories and policies. WIEGO Working Paper No.1. Available from http://wiego.org/sites/wiego.org/files/publications/files/Chen_WIEGO_WP1.pdf [Accessed 23 April, 2014].

Dardano, C., 2003. Carribbean regional working group on street food vendors. Report of FAO, PAHO and BNSI. Available from: http://ftp.fao.org/es/esn/food/carribean_report.pdf.

Flodman-Becker, K., 2004. The informal economy. SIDA. Available from www.sida.se/publications [Accessed 8 March 2014].

Hart, K., 1973. Informal Income opportunities and urban employment in Ghana. The Journal of Modern African Studies, 11(1): 61-89 Available from http//dx.doi.org/10.1017/So022278X00008089 [Accessed 31 March 2014].

Hernando, S., De., 2000. Mystery of capital: Why capitalism triumphs in the west and fails everywhere else. New York: Basic Books.

Kusakabe, K., 2006. Policy issues on street vending: An overview of studies in Thailand, Cambodia and Mongolia. Bangkok: International Labour Office.

Ndhlovu, P.K., 2011. Street vending in Zambia: A case of Lusaka district. Unpublished dissertation submitted in partial fulfilment of the requirements for the master arts in development studies, Graduate School of Development Studies, International Institute of Social Sciences, The Hague, The Netherlands. Available from www.thesis.eur.nl/pub/10844/RP_Final_Pity_Ndhlovu.pdf [Accessed 26 April 2014].

Njaya, T., 2014. Science nature, operations and socio-economic features of street food entrepreneurs of Harare, Zimbabwe: IOSR Journal of Humanities and Social, 19(4): 49-58. Available from http://www.iosrjournals.org/iosr-jhss/papers/Vol 19-issue4/Version-3/Ho19434958.pdf

[Accessed 21 April 2014].

Roever, S., 2010. Street trade in Latin America: Demographic trends, legal issues and vending organisations in six cities in Bhowmik, S.K. ed. Street vendors in gthe global urban economy.New Delhi: Routledge. 
Roever, S.C., 2005. Negotiating formality: Informal sector, markets and state in peru. Unpublished dissertation submitted in partial satisfaction of the requirements for the degree of Doctor of Philosophy in Political Science, University of California, and Berkeley, USA. Available from http://wiego.org/sites/wiego.org/files/publications/files/Roever-Negotiating-Formality.pdf [Accessed 26 April 2014].

Sinha, S. and S. Roever, 2011. India's national policy on urban street vendors. WIEGO Policy Brief (Urban Policies) No.2.

Women in Informal Employment Globalisation and Organising, 2012. Street vendors. Available from http://wiego.org/informal-economy/occupational-groups/street-vendors.

ZIMSTAT Zimbabwe National Statistics Agency), 2012. Census 2012 preliminary report. Harare: ZIMSTAT.

\section{BIBLIOGRAPHY}

Bromley, R.G.F. and P.K. Mackie, 2009. Displacement and the new spaces for informal traders in the Latin American city centre. Urban Studies, 46(7): 1485-1506.

Hernando, S.D., 2002. The other path: The economic answer to terrorism. New York: Basic Books. 